\title{
Non-Foodborne Swine Zoonotic Diseases
}

\author{
Branko Angjelovski, Toni Dovenski
}

Ss. Cyril and Methodius University in Skopje, Faculty of Veterinary Medicine, Lazar Pop-Trajkov 5-7, 1000 Skopje, Republic of Macedonia

\author{
Citation: Angjelovski B, Dovenski T. Non- \\ Foodborne Swine Zoonotic Diseases. Maced J \\ Med Sci. 2013 Mar 15; 6(1):92-101. \\ http://dx.doi.org/10.3889/MJMS.1857-5773.2013.0280. \\ Key words: swine; zoonoses; non-foodborne; \\ diseases; emerging. \\ "Correspondence: Branko Angjelovski. Ss. \\ Cyril and Methodius University in Skopje \\ Faculty of Veterinary Medicine, Lazar Pop- \\ Trajkov 5-7, 1000 Skopje, Republic of \\ Macedonia. E-mail: brankoaa@yahoo.com \\ Received: 24-Sep-2012; Revised: 31-Jan- \\ 2013; Accepted: 03-Feb-2013; Online first: \\ 19-Feb-2013 \\ Copyright: (c) 2013 Angjelovski B. This is an \\ open-access article distributed under the terms \\ of the Creative Commons Attribution License, \\ which permits unrestricted use, distribution, \\ and reproduction in any medium, provided the \\ original author and source are credited. \\ Competing Interests: The author have \\ declared that no competing interests exist.
}

\begin{abstract}
The aim of this paper is to give an overview of novel swine non-foodborne zoonotic diseases that have been prominent in the last decade in swine industry. The number of swine present worldwide and the large percentage of population that consume pork, swine represent significant reservoir of potential zoonoses. Numerous of human cases of swine non-foodborne zoonoses were reported all over the world. Although much progress is made to control swine non-foodborne zoonoses, we must remain vigilant to identified and control novel swine emerging zoonoses.
\end{abstract}

\section{Introduction}

Any disease which is naturally transmissible from vertebrate animals to humans is defined as a zoonosis [1]. Zoonotic diseases can be transmitted in variety of ways: via contaminated food, direct contact or close proximity, vectors and airborne transmission. From this point of view zoonotic diseases can be divided into foodborne and non-foodborne. About 75 $\%$ of new emerged diseases over past 10 years that affected humans have originated from animals or animal products [2]. This number is expected to increase due to intensive changes in agricultural practice, human population growth, evolution of pathogens and international trade [3]. Swine have been included in transmission of many infectious agents to humans acting as primary or intermediary source and reservoir of infection [4]. Swine industry has expanded its production units all over the world, because of increased consumption of pork as a central source of protein. It is estimated that about 99 million metric tons of pork was consumed worldwide in 2006 [5]. Therefore, the risk from transmission of potential pathogens from swine and their products is much higher in individuals who work as caretakers on farms, butchers and veterinarians who are in direct contact with live animals and carcasses and the consumers via contaminated food. The definition about non-food borne zoonotic disease is: any disease which can be transmitted from animals to humans primarily via methods that do not include a food vector [6]. Despite already known swine foodborne zoonotic diseases (Salmonellosis, Yersinia enterocolitica, Toxoplazma gondii, Campylobacter spp. etc.) there are many non-foodborne zoonotic diseases. Swine influenza virus has emerged as a non-foodborne zoonotic agent in previous several years, but new pathogens like methicilin-resistant Staphylococcus aureus (MRSA), Clostridium difficile, Streptococcus suis and some others have implicated swine as a potential vehicle of transmission [4]. The aim of this paper is to give an overview of selected 
novel swine non-foodborne bacterial and viral zoonoses that have been prominent in the modern swine production units in the last decade.

\section{Methicilin-resistant Staphylococcus aureus (MRSA)}

Staphylococcus aureus is a common organism found on the skin and mucous membranes of animals and humans. It can function as an opportunistic pathogen causing superficial and/or invasive infections [6]. It is Gram positive and forms white to golden opaque colonies with a double zone of haemolysis on sheep blood agar. Methicillin resistant Staphylococcus aureus (MRSA) colonization has recently been identified in pigs and people who work with pigs, raising concerns about the role of pigs as reservoirs of MRSA for human infection [7]. Besides skin infections, $S$. aureus has also been associated in swine with septicemia, mastitis, vaginitis, metritis, osteomyelitis and endocarditis [8]. Subset of $S$. aureus (MRSA) are resistant to methicillin with this resistant encoded by the mecA gene, which codes for penicillin-binding protein $2 a$ that confers resistance to all beta-lactam antimicrobials [9]. First it was thought that transmission of MRSA was only from human to animal, with direct contact of the hands of human and anterior nostrils of the animal. Today there is strong evidence that MRSA can be transmitted in both directions. When once exposed to MRSA animal become colonized and may serve as reservoirs for infection to other animals and their human handlers respectively $[10,11]$.

Table 1: Recently published reports of ST398 MRSA infections in humans with close contact to positive pigs and their family members.

\begin{tabular}{|c|c|c|c|}
\hline Country & $\begin{array}{c}\text { Positive } \\
\text { humans \% }\end{array}$ & $\begin{array}{l}\text { Positive Pigs } \\
\text { and pig } \\
\text { farms }\end{array}$ & Author-year \\
\hline Netherlands & $>20 \%$ & $39 \%$ pigs & $\begin{array}{c}\text { Wulf and } \\
\text { Voss } 2008 \\
(14)\end{array}$ \\
\hline Belgium & $38 \%$ (49) & $\begin{array}{c}44,2 \% \\
(663 / 1500) \\
\text { pigs }\end{array}$ & $\begin{array}{c}\text { Denis et al. } \\
2009 \text { (15) }\end{array}$ \\
\hline $\begin{array}{l}\text { Ontario, } \\
\text { Canada }\end{array}$ & $\begin{array}{c}25 \%(5 \text { of } \\
25)\end{array}$ & $\begin{array}{c}45 \%(9 / 20) \text { pig } \\
\text { farms }\end{array}$ & $\begin{array}{l}\text { Khanna T et } \\
\text { al. } 2008 \text { (7) }\end{array}$ \\
\hline Germany & $\begin{array}{l}86 \%(97), 5 \% \\
\text { (4) their } \\
\text { family } \\
\text { members }\end{array}$ & $\begin{array}{l}\text { In a study in } \\
47 \text { positive } \\
\text { farms }\end{array}$ & $\begin{array}{l}\text { Cuny C et al. } \\
2009 \text { (16) }\end{array}$ \\
\hline U.S.A & $45 \%(9 / 20)$ & $\begin{array}{c}49 \% \\
(147 / 299) \\
\text { pigs }\end{array}$ & $\begin{array}{l}\text { Smith and } \\
\text { al.2009 (17) }\end{array}$ \\
\hline
\end{tabular}

In 2005, a new MRSA strain was identified in Netherlands that was resistant to digestion with the restriction endonuclease Sma1 when typing with pulsed-field gel electrophoresis (PFGE) was attempted, and was associated with contact with pigs.
This strain belongs to a multilocus sequence type ST398 [12]. Microbiological testing in Denmark confirmed that pigs were source of MRSA CC398 (ST398) [13]. Recent studies (summarized in table 1) have shown high prevalence of ST 398 MRSA strain among humans and pigs [7, 14-17]. In the Netherlands, Germany, Denmark and China infection with ST398 in humans have been described including mastitis [10], endocarditis [18], ventilator-associated pneumonia [19], wounding infections [10] and skin and soft tissue infection (SSTI) [20].

Transmission of ST 398 MRSA from farmworkers to their family members has been reported, but spread into the general community seems to be infrequent [16, 21]. High frequency of MRSA among the group of pig farmers (760 times greater than general Dutch population) indicated that their profession put them at risk for MRSA colonization [12]. Wasswnberg et al. reported $72 \%$ less transmission of ST 398 MRSA strain in Dutch Hospitals compared with other MRSA genotypes. The lower transmission may be due to different pathogenrelated and patient-related characteristic [22]. Transmission between humans and pigs with ST398 were reported in three family members, two workers, farmer and his pigs. All cases except initial case (mother with mastitis) were solely colonized without clinical signs [10]. ST398 MRSA ussualy is associated between livestock infected pigs and people exposed to animals [23]. Surprisingly high prevalence of ST398 (17.1\%) was found in prospective cohort in adults in four hospital in Beijing, China. No apparent contact with animals in all positive cases was found [20]. Two ST398 strains in Hong Kong were isolated from patients with bacteremia without previous relation with pig farming [24]. That high prevalence of community acquired ST398 MRSA in this region is probably because whole genome sequencing of European ST398 has revealed that it lacked virulence factors such as enterotoxins and phage-encoded toxins [20]. Altought ST398 was found in a number of medical and surveillance reports in many countries (Hong Kong, China, Italy, Germany, Denmark, The Netherlands, Sweden, Dominicana, Scotland, Austria, Spain, Belgium, Norway and Canada) the clinical importance is not to much significant as other human strain in the community and hospitals [23]. Most prevalent strains associated with communityassociated MRSA (CA-MRSA) human infection is USA300 and USA100 for hospital-associated MRSA HA-MRSA respectively [25]. ST 398 compared with other MRSA strain is susceptible to most of antiboiotics but it show almost universal resistance to the tetracyclines [13]. Hypothetically the diversity of ST 398 all over the world may be linked with high amount of tetracyclines used as growth promoters in pig farming. The low prevalence ST 398 infections in the community in the european region (The Netherlands) compared with asian region, also can be explained with the national policy that enforce strict screening and isolation of all cases who are 
considered at high risk for MRSA when admitted in to a hospital [12].

Public health agencies in the United States and Europe have not found evidence that contaminated meat contribute to an increased risk of MRSA [6]. From the studies about LA-MRSA ST 398 strain it is still unknown whether this is novel MRSA strain or is already has been previously present on livestock farms. Additional research should be done with aim to investigate spectrum and spread of this MRSA strain in general population and to identify other potential zoonotic MRSA strains [4].

\section{Streptococcus suis}

Streptococcus suis is an emerging zoonotic agent that has increased in importance in the last 5 years. Natural habitat of Streptococcus suis is the upper respiratory tract, particularly the tonsils and the nasal cavities of the pigs [26]. Streptococcus suis is common in domestic swine worldwide and 35 various serotypes have been described [27]. Clinical signs in pigs include central nervous system signs (head tilt and paddling), arthritis and polyserositis [6]. In humans $S$. suis usually produces purulent meningitis, although endocarditis, cellulitis, peritonitis, rhabdomyolysis, arthritis, spondylodiscitis, pneumonia, uveitis, and endopthalmitis have also been reported [28]. Most of human infections are occurring among veterinarians, pork handlers and slaughterhouse workers who are in direct contact with swine, raw pork or pig viscera. Transmission of infection is usually trough the skin via cut, infected wound or abrasion [29].

First case of human infection was reported in Denmark in 1968 [30]. $S$.suis serotype 2 is the most frequently associated in humans and pigs and it is the most prevalent serotype that has been isolated from clinical material from pigs in Europe [31]. Streptococcus suis in pigs is spread worldwide: North America, Brazil, Europe, Australia and New Zealand [32]. Since, first reported case of human infection with S. suis, increasing number of humans infections have been reported in many countries [30]. First case of human infection in North America was reported in 2006 in 59 year old male farmer [33]. The number of reported human $S$. suis cases has increased significantly in past few years. In review published in 2007409 cases were reported [30], but in 2009 this number has increased to $>700$ cases, where the most cases originate from Southeast Asia (Table 2). Total of 215 cases, including 38 deaths of $S$. suis human infections, occurred in China. All of the infected people had contact with pigs infected with $S$. suis type 2 [34]. S. suis was detected in 151 (33.6\%), from total of 450 patients with suspected bacterial meningitis in one prospective study [35]. Serotype 2 was the most commonly detected organism in Viet Nam, and is responsible for acute meningitis in adults [36].
Table 2: S.suis human cases reported worldwide, by country and number of new cases reported in two year period.

\begin{tabular}{lccc}
\hline Country & Pre- 2006 & Till 2008 & $\begin{array}{c}\text { New cases } \\
\text { from 2006 to } \\
\text { China }\end{array}$ \\
Vietnam & 283 & 332 & $\mathbf{2 0 0 8}$ \\
Thailand & 0 & 293 & $\mathbf{4 9}$ \\
Netherlands & 47 & 118 & $\mathbf{2 9 3}$ \\
UK & 34 & 41 & $\mathbf{7 1}$ \\
Germany & 6 & 15 & $\mathbf{7}$ \\
Spain & 6 & 7 & $\mathbf{9}$ \\
France & 6 & 6 & $\mathbf{1}$ \\
Croatia & 5 & 7 & $\mathbf{0}$ \\
Denmark & 4 & 2 & $\mathbf{2}$ \\
Belgium & 3 & 12 & 0 \\
Japan & 2 & 2 & 9 \\
Italy & 2 & 2 & $\mathbf{0}$ \\
USA & 2 & 2 & $\mathbf{0}$ \\
Argentina & 1 & 1 & $\mathbf{0}$ \\
Austria & 1 & 1 & $\mathbf{0}$ \\
Canada & 1 & 1 & $\mathbf{0}$ \\
Hungary & 1 & 1 & $\mathbf{0}$ \\
Greece & 1 & 1 & $\mathbf{0}$ \\
New Zealand & 1 & 2 & $\mathbf{0}$ \\
Singapore & 1 & 1 & $\mathbf{1}$ \\
Sweden & 1 & 1 & $\mathbf{0}$ \\
\hline Total & 1 & $\mathbf{8 4 9}$ & $\mathbf{0}$ \\
\hline
\end{tabular}

Human S. suis cases are most often reported from countries where density of pigs is high (Figure1) and where pig-rearing is common practice [28]. Human $S$. suis infections have been described including multiorgan failure, deafness, purulent meningitis, subacute meningitis, spodylodiscitis and septicaemia. All of this cases were associated with exposure to pigs [37-40].

Serological studies have shown that the infections with this organism are common in swineexposed individuals (veterinarians, farm workers, veterinary inspectors) $[41,42]$, and it has been shown that laboratory misidentify of this organism may be the reason for the lack of reports of human cases in the United States [43].

Streptococcus suis is an important emerging pathogen responsible for causing meningitis and septicaemia in humans and pigs. Diseased pigs with and without clinical symptoms play an important role in the transmission between humans. Sporadic infections with $S$. suis in humans have been reported worldwide. Most of the infections occur between individuals who have direct contact with live pigs, pork and pig viscera. In North America, human S. suis infections are quite rare in contrast to infections in Southeast Asia. This finding can be explained with the fact that pig density in Southeast Asia is very high, as well as absence of preventive measures in slaughtering practice and consumption of undercooked pig products. Traditional consumption and differences in swine husbandry also play significant role for the transmission of this pathogen [4]. 


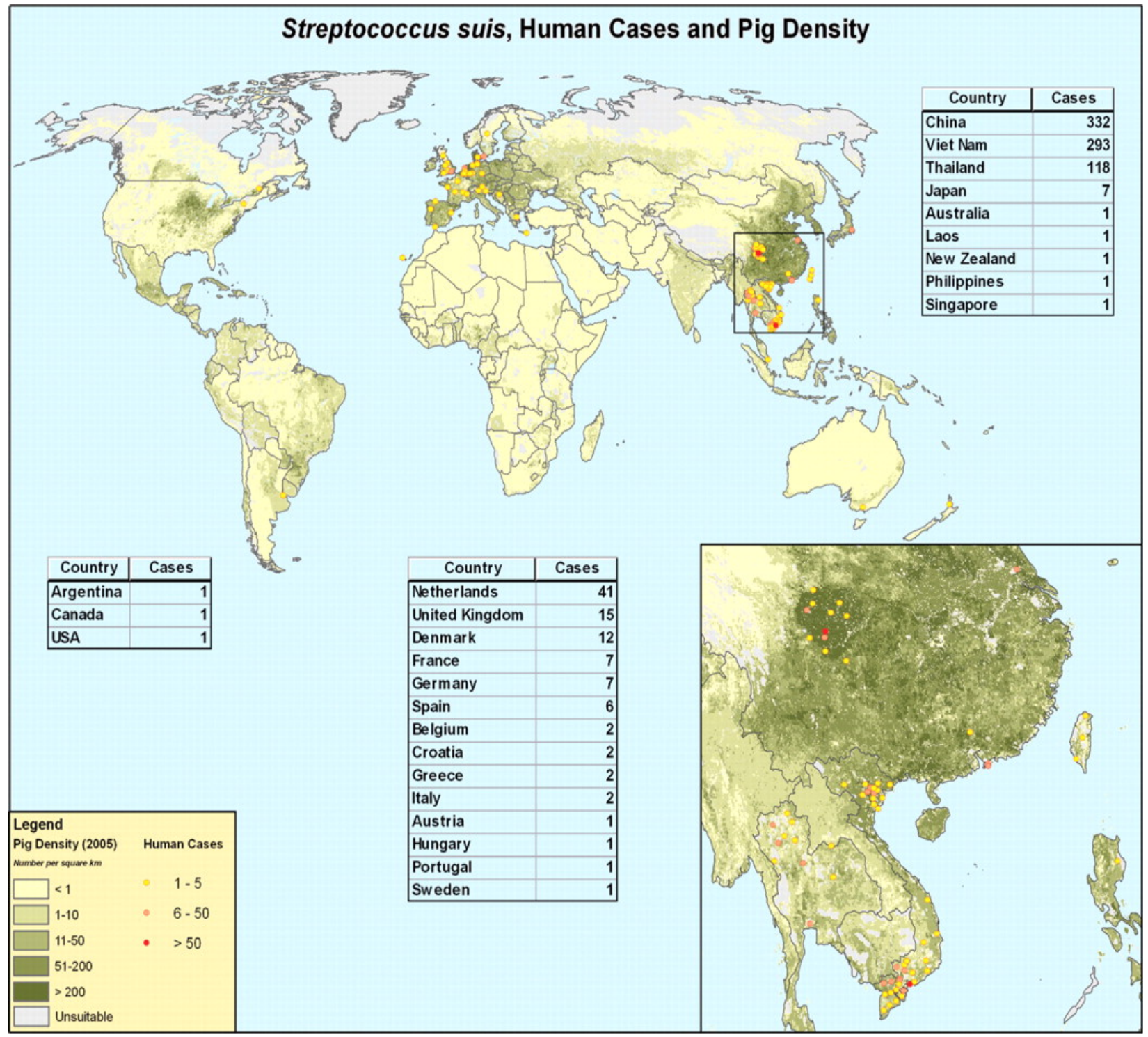

Figure 1: World map of human Streptoccocus suis cases with background pig density data.

\section{Clostridium difficile}

Clostridium difficile is a gram positive bacteria which is able to form spores. It was described for the first time in 1935 as a part of normal gut flora in human neonates [44]. Clostridium difficile in humans it is responsible for causing pseudomembranous colitis with severe gut diseases in some cases [45]. It is also a common agent of colitis in neonate pigs [46]. Many studies have suggested that risk factor for development of disease is exposure with antibiotics in both humans [47-49] and pigs [50, 51]. Antibiotics cause disruption of normal gut flora of the host and allow Clostridium spores to germinate. In the last decade epidemiology of $C$. difficile has dramatically changed. Several studies have examined the prevalence of $C$. difficile shedding among pigs in North America and worldwide [6]. Because C. difficile is an agent which causes enteritis in neonatal pigs (from birth to 7 days of age), prevalence of faecal shedding in piglets is higher than in adult swine. There is a significant decrease in colonization over time with $74 \%$ in piglets on day $2.56 \%$ on day $7.40 \%$ on day 30 , $23 \%$ on day 44 and $3.7 \%$ on day 62 [52]. An epidemic of high virulent strain of $C$. difficile was reported recently in Europe and North America. This strain was hipervirulent and capable to produce protein toxins $A$, $B$ and so called binary toxin [53]. The same $C$. difficile strain caused outbreak of enteritis in neonatal piglets in Europe and USA and was identified with PCR as a ribotype 078 [46]. Several of C. difficile types have been described as enteric pathogen in animals (pigs, horses, goats, sheep, dogs, cats, cattle), but most prevalent strain in pigs (83\%) and cattle (94\%) was C. difficile ribotype 078 [54]. Also, this is the third most common strain found in humans in Europe [55]. First case of $C$. difficile ribotype 078 toxinotype $V$ in pigs was found in Slovenia [56]. Clostridium difficile infection (CDI) can present a severe disease in humans particularly when it caused by hipervirulent 
strain characterized as North American pulsed-field rybotype 27 . Outbreaks of CDI associated with this strain have been reported in United States, Canada and Europe [57]. In a prevalence study on hospital strains performed in 2005 ribotype 078 was the $11^{\text {th }}$ most prevalent type in Europe representing 2.8\% (9/322) of all toxigenic strains. In total of 14 coutries involved in study only in Greece ribotype 078 was represented with more than $10 \%$ of all strains [58]. The number of human infections with $C$. difficile ribotype 078 appears to be increasing associated with high levels of mortality similar as other hipervirulent strain C. difficile 027 [59]. Recently the prevalence of C. difficile ribotype 078 has increased from 3 to $13 \%$ in several countries in Europe [49]. In the USA the prevalence of ribotype 078 infections in humans has dramatically increased from $0.02 \%$ to $1.3 \%$ (pre-2001 to 2006), and rybotype 078 was increasingly associated with community-aquired CDI [60]. Goorhuis et al. have shown difference between infections in humans with ribotype 027 and 078 respectively. Patients infected with rybotype 078 were younger (67.4 vs. 73.5) and had more frequently community-associated CDI (17.5\% versus $6.7 \%$; odds ratio $=2.98 ; 95 \%$ confidence interval $=2.11-8.02$ ) than patients infected with ribotype 027 [57]. High genetic similarity of $C$. difficile rybotype 078 was found between humans and pigs [56, 57]. Some studies suggest that $C$. difficile contaminate retail food including meat products, vegetables and salads. With abundant evidence that food contains toxigenic strains of $C$. difficile, it still remains that food-borne transmission is unproven [55].

Clostridium difficile is an emerging pathogen responsible for causing diarrhea in neonatal pigs and pseudomembranous colitis in humans. Many studies in Europe reported that strains of $C$. difficile in pigs and humans are genetically identical and confirmed the zoonotic potential [56]. The number of communityacquired $C$. difficile infections is increasing worldwide and the opinion that animals are a reservoir for human infection still stands. Besides the genetic homology of the $C$. difficile strains in pigs and humans, the question about the source and the transmission of the infection between humans and pigs still remains unanswered.

\section{Swine A influenza viruses}

Influenza viruses are members of the virus family Orthomyxoviridae. They are pleomorphic, enveloped viruses approximately 80-120 nm in diameter. Influenza viruses encode 10 or 11 viral proteins on eight separate segments of negativesense RNA [61].

Pigs posse's receptors for avian and human viruses and serve as potential danger for novel reassortment strains [62]. The well known pandemic of swine influenza was in 1918-1919. During this pandemic, there were outbreaks of influenza in swine and humans that were caused from a single infection agent [4]. First influenza virus in swine was isolated in 1930 in North America [63]. In 2009, there was an outbreak of a novel pandemic H1N1 virus in humans. This strain originated from a reassortment between swine, avian and human lineages of influenza viruses [64]. In 2009, H1N1 outbreaks were reported in 69 countries with 21940 cases including 125 deaths [65]. Except the 2009 outbreak, human cases of pH1N1 influenza have been sporadicaly reported. Before the outbreak in 2009, another outbreak in 1976 occurred in Fort Dix (New Jersey), where 1 person died from $230 \mathrm{H} 1 \mathrm{~N} 1$ infected soldiers $[62,66]$. In the period between 1958 and 2007, 50 human cases of classical swine influenza were reported and most of them involved individuals which had close contact with swine [62]. From December 2005 till February 2009, 11 cases of triple-reassortant $\mathrm{H} 1$ infections in humans have been reported in the United States, including a report of pig-to-human transmission with a strain currently circulating in the pig population in U.S at the Ohio County Fair in 2007 [67, 68]. From the 11 infected patients, eight of them had contact with clinically ill pigs [67]. The number of pH1N1 influenza reports worldwide is small compared to the number of people that were in close contact with pigs [61]. Human H3N2 viruses also have been frequently recovered from pigs in Asia and occasionally from Europe and North America [61]. Influenza viruses of subtype H3N2 are endemic in most pig population world-wide, where they persist many years after antigenic counterparts disappeared from humans, and therefore present a reservoir of virus which may in the future transmitted to a human population [69]. During influenza outbreak in 1998 in four swine herds in U.S two antigenically distinct $\mathrm{H} 3 \mathrm{~N} 2$ viruses were isolated from infected animals: a double-reassortant virus containing genes similar to human and swine viruses, and triple- reassortant virus with genes similar to those of human, swine and avian influenza viruses [70]. The emergency of an H3N2 virus with triplereassortant internal gene (TRIG) cassette consisting genes from human (HA, NA and PB1), avian (PB2 and $P A$ ) and swine (NP, $M$ and NS) viruses and human H1N1 and H1N2 viruses in 2003 and 2005 in U.S. swine population exemplify influenza virus transmission from human to swine [70, 71]. In European swine H3N2 viruses were derived from descendans of the 1968 "Hong Kong" pandemic human virus, but they have evolved further in reassortant $\mathrm{H} 3 \mathrm{~N} 2$ viruses human-like and avian-like internal genes [61]. In contrast to U.S. in Europe H3N2 influenza viruses related to human strain continued to circulate in pig population.long after they disappeared from the human population [69]. This sharp difference between high level of H3N2 infections in Europe to the low prevalence in pigs in North America may suggest that virus is not established in American swine population, but occurs only by infrequent introduction from infected human [69]. Situation in Asia is more complex than Europe and North America. H3N2 viruses have been 
repeatedly transmitted from people to pigs since 1970s, and variants of Hong Kong/68 pandemic virus cocirculate in pigs with contemporary human H3N2 viruses [72-74]. Efficient transmission of human influenza viruses among pigs it seems requires adaptation to the new host species. Thus, H3N2 viruses that have been maintained in pigs in North America and Europe are reassortants with a mix of human and swine-adapted genes. Serological studies have shown that antibodies may be present up to $23 \%$ in humans exposed to pigs, but they are of limited value because of the difficulty to differentiate between swine and human influenza viruses [66]. The occurrence of influenza virus infections in pigs poses two important public health issues: infection of people with swine influenza viruses and the potential of pigs to serve as hosts for the creation of novel viruses of pandemic potential for the human population. Pigs remain important because of the genetic origin of the 2009 pH1N1 virus outbreak. This virus contains a unique combination of gene segments from North American and Eurasian lineages [75, 76].

\section{Hepatitis E virus}

Hepatitis $E$ virus (HEV) is a single-stranded, positive-sense RNA virus of the genus Hepevirus. $\mathrm{HEV}$ is an important zoonotic pathogen causing more than $50 \%$ of all human cases of acute hepatitis in endemic countries [77]. Mortality rates are low in human population, except in Africa and Asia where in the third trimester of pregnancy, mortality can reach more than $20 \%$ [78]. HEV is transmitted by faecaloral route and is a public health concern in areas with poor sanitation and public health infrastructure [77]. Regardless the fact that HEV is endemic in human population, in pigs HEV is widespread in swine farms worldwide. The infection in pigs occurs at about 2 to 3 months of age and they have transient viremia for about 1 to 2 weeks. Feces from infected pigs contains large amount of virus and are likely the main source of infection [79]. Fecal shedding of the virus from the infected pigs lasts for about 3-7 weeks [79]. HEV was first isolated from domestic pigs in the Midwestern United States in 1997 [4]. There are five genotypes of HEV known to date. Genotypes 1 and 2 infect only humans, but genotypes 3 and 4 infect humans and animals including swine [77, 80]. First example of human infection with HEV genotype 3 was reported in United States and was similar with HEV genotype 3 isolated from a swine herd in United States [81, 82].Genotypes 3 and 4 are less virulent in humans than genotypes 1 and 2 [83]. Molecular studies have shown that swine and human isolates from one geographical region are very similar and are different from those in other geographical regions [84, 85]. In developing countries where HEV is endemic, even genotype 3 and 4 are present in the local swine herds, virulent genotypes 1 and 2 were the most frequently recovered from human cases of hepatitis $E$ [86]. In the industrialized countries where more virulent genotypes 1 and 2 are not present, less virulent genotypes 3 and 4 have been frequently isolated from occasional cases of clinical hepatitis $E$ [83]. In United States and Taiwan, people who are in close contact with swine are associated with increased risk from seroconversation but without clinical disease [87-89]. Swine veterinarians in USA are 1.51 times more positive for anti-HEV antibodies than other blood donors [88]. The prevalence of IgG anti-HEV is very high in some developing countries such as Egypt with more than $70 \%$ of the human population positive for IgG anti-HEV [79]. High prevalence of anti-HEV Ig in healthy individuals in nonendemic areas may be linked with inapparent infections with less virulent strains of HEV derived from swine or other domestic or wild animals [83]. The varieties between high seroprevalence and low frequency of hepatitis $E$ infection in these areas indicate that zoonotic spreading of virus is at least partly responsible [77]. More than $20 \%$ of pigs and pig production units excreting large quantity of HEV [78] in watercourses most probably as a consequence of run-off from outdoor pig farms [77]. HEV has been isolated in slurry lagoons from pig farms [78, 90] and from sewage works in pig slaughterhouses [91]. Those data suggested that hepatitis $E$ infections in humans with limited pig contact in endemic areas may be associated with faecal contamination of waterworks and poor sanitary conditions. Swine veterinarians and pig farmers in both developing and developed countries are at high risk for HEV infection. Despite the fact that HEV is endemic in developing countries, sporadic infections were reported in North America, Japan, Australia, New Zeeland and Europe $[92$, 93]. Numerous serological studies about exposure to HEV obtained in both developed and developing countries have confirmed that the infection is very common, but the clinical form is rare in developed countries [6].

\section{Nipah virus}

Nipah virus (NiV) is a negative-stranded RNA virus of the family Paramyxoviridae. Both Nipah and Hendra viruses are the sole members of the genus Henipavirus [94]. It is dangerous zoonotic agent, causes fever and headache in humans, and can lead to a deadly encephalitis. In pigs, signs are manifested with respiratory and febrile illness, tetanic spasms, lateral recumbence, spastic paresis and uncoordinated gait [95]. Between September 1998 and April 1999, after spreading as a unrecognised respiratory or encephalitic infection in Malaysian pigs, NiV appeared in the human population and caused fatal encephalitis [96]. Over 400 cases of NiV in humans were reported with approximately 200 deaths in Malaysia, Singapore, Bangladesh and India [96]. The virus, isolated in 1999 from cerebrospinal fluid (CSF) of human fatal cases was named as Nipah virus [97]. It is presumed that this outbreak is a result of virus 'jumping' species into farmed domestic pigs 
[94, 98-100]. In Malasyia, virus was primary spreading by movement of infected pigs between farms, states and internationally to Singapur, where abattoir workers became infected while processing pigs (95). The natural reservoir of the virus is fruit bats from the genus Pteropus [101]. Human infection with the virus is linked to direct contact with infected pigs and especially with their body fluids [97]. Parashar et al. in their findings confirmed that close contact with pigs especially with sick pigs (handling of pigs, feeding, treating, assisting with farrowing, treatment and removal of sick and death pigs), were strongly associated with infection in humans [102, 95]. Pigs are considered the amplifying host for human infection and it is believed that they are the main source of infection [101]. The major route of excretion of Nipah virus from pigs is via the airways. It is suggested that the larger drops via the sputum (rather than fine aerosol) are more likely linked with the transmission of the infection [103]. Besides pigs, other domestic animals are also susceptible to Nipah virus. Large numbers of clinically affected dogs died during these outbreaks in swine farms [94, 98]. In the outbreak in Malaysia, Nipah virus was isolated from the kidney of affected dog [94]. This may suggested that virus could be spread through urinary secretion by domestic carnivores. Cats are also susceptible to infection and they excrete the virus in urine [104]. Before the outbreak in Malaysia, the recent outbreaks of NiV infection in Bangladesh and India had higher fatality rates where human to human transmission was reported [105-108]. Transmission of the virus in humans with fatal encephalitis without close contact with pigs has been reported in Bangladesh in 2001, 2003 and 2004 [109].

\section{Japanese encephalitis}

Japanese encephalitis virus (JEV) is a zoonotic vector-borne viral disease which is mainly transmitted by the mosquito Culex tritaeniorrhynchus [110]. It was first isolated in 1933 in Japan from humans cases with encephalitis [111]. Approximately $25 \%$ of clinical JEV cases are fatal, $50 \%$ have some form of neurological sequelae, such as quadriplegia or mental retardation, and $25 \%$ fully recover [112]. Wading birds are considered the primary endemic hosts of JEV, but pigs are important in the transmission cycle because they are the only known mammals to fulfill the criteria as an amplifying host for the virus [113]. They develop viremia that lasts 2-4 days and are capable to infect various mosquito species [114]. To date there is no evidence that human contact with blood from infected viremic pigs is a risk factor. In viremic state they only infect certain mosquito species. With bitting those infected insects can cause infection in humans [112]. Seroprevalence rates in other animals such as dogs and sheep are high but too low to infect mosquitoes [115]. The distribution of JEV occurs mostly in East, Southeast and South Asia and in the South Pacific [116]. It is believed that JEV is responsible for more than 40.000 annual cases of encephalitis with 10000 deaths [112]. Besides pigs, horses and donkeys could serve as a reservoir for the virus. In some regions of Asia (Bangladesh, Cambodia, Indonesia, Laos, Myanmar, North Korea and Pakistan), increasing pig populations, intensified rice farming and lack of vaccination and surveillance have been linked to increasing human infections [115]. In Japan, that trend was reversed. During the last 40 years, the number of pigs in Japan has increased while the number of farms has decreased. Rasing pigs in modern facilities drastically declined the number of JEV cases in humans [116].

\section{Conclusion}

We can conclude that swine represent a significant source of non foodborne zoonoses. Most of the infections occurring in areas where sanitation measures are poor and density of animals is high. Individuals with occupational contact with swine, like veterinarians, butchers, caretakers, farmers, have high risk for infection. Modernization of swine industry has showed that some swine zoonoses were drastically reduced. Our review is certalnly incomplete. Additional pathogens such as Norovirus, Ebola reston virus and porcine endogenous retroviruses have also been implicated in zoonotic transmittion between pigs and humans. Although much progress is made to control swine non foodborne zoonoses, we must remain provident to identify and control novel emerging swine zoonoses.

\section{Acknowledgements}

Publication fee for this review article was covered by Ss Cyril and Methodius University Skopje PhD School.

\section{References}

1. Zoonoses and veterinary public health (VPH). World Health Organization Web site. http://www.who.int/zoonoses/en/. Accessed July 25, 2012.

2. Zoonotic diseases. European Food Safety Authority. Web site http://www.efsa.europa.eu/en/topics/topic/zoonoticdiseases.ht m. Accesssed July 25, 2012.

3. Woolhouse ME, Gowtage SS. Host range and emerging and reemerging pathogens. Emerg Infect Dis. 2005;11(12):184247.

4. Smith TC, Harper AL, Nair R, et al. Emerging Swine Zoonoses. Vector borne Zoonotic Dis. 2011;11(9):1225-34.

5. United States Department of Agriculture. Foreign Agricultural Service Commodity and Marketing Programs. Livestock and Poultry: World Markets and Trade, November 2006.

6. Funk J, Wagstrom E. Preharvest Food Safety, Zoonotic Diseases, and the Human Health Interface. Zimmerman JJ, Karriker LA, Ramirez A, Schwartz KJ, Stevenson GW, eds. 
Diseases of swine. 10th ed. Chichester, West Sussex: John Wiley and Sons, Inc., 2012:12.

7. Khanna T, Friendship R, Dewey C, Weese JS. Methicillin resistant Staphylococcus aureus colonization in pigs and pig farmers. Vet Microbiol. 2008;128:298-03.

8. Frana TS. Staphylococcosis. Zimmerman JJ, Karriker LA, Ramirez A, Schwartz KJ, Stevenson GW, eds. Diseases of swine. 10th ed. Chichester, West Sussex: John Wiley and Sons, Inc., 2012:61.

9. Kluytmans JA JW. Methicillin-resistant Staphylococcus aureus in food products: cause for concern or case for complacency? Clin Microbiol Infect. 2010;16(1):11-15.

10. Huijsdens XW, van Dijke BJ, Spalburg E, et al. Communityacquired MRSA and pig-farming. Ann Clin Microbiol Antimicrob. 2006. Available at: Web site http://www.annclinmicrob.com/content/pdf/1476-0711-5-26.pdf. Accessed on January 08, 2012.

11. Baptiste KE, Williams $\mathrm{K}$, Williams $\mathrm{NJ}$, et al. Methicillin-resistant Staphylococci in companion animals. Emerg Infect Dis. 2005;1:1942-44.

12. Voss A, Loeffen F, Bakker J, Klaassen C, Wulf M. Methicillin resistant Staphylococcus aureus in pig farming. Emerg Infect Dis. 2005;11(12):1965-66.

13. Lewis $\mathrm{HC}$, Mølbak $\mathrm{K}$, Reese $\mathrm{C}$, et al. Pigs as Source of Methicillin- Resistant Staphylococcus aureus CC398 Infections in Humans,Denmark. Emerg Infect Dis. 2008;14(9):1383-89.

14. Wulf $M$, Voss A. MRSA in livestock animals an epidemic waiting to happen? Clin Microbiol Infect. 2008;14(6):519-21.

15. Denis $O$, Suetens $C$, Hallin $M$, et al. Methicillin resistant Staphylococcus aureus ST398 in swine farm personnel, Belgium. Emerg Infect Dis. 2009;15(7):1098-01.

16. Cuny C, Nathaus R, Layer F, Strommenger B, Altmann D, Witte W. Nasal Colonization of Humans with Methicillin Resistant Staphylococcus aureus (MRSA) CC398 with and without Exposure to Pigs. PLoS ONE. 2009;4(8):1-6.

17. Smith TC, Male MJ, Harper $A L$, et al. Methicillin-Resistant Staphylococcus aureus (MRSA) Strain ST398 Is Present in Midwestern U.S. Swine and Swine Workers. PLoS ONE. 2009;4(1):1-6

18. Ekkelenkamp MB, Sekkat M, Carpaij N, Troelstra A,Bonten MJ. Endocarditis due to meticillin-resistant Staphylococcus aureus originating from pigs. Ned Tijdschr Geneeskd. 2006;150:2442-47.

19. Witte W, Strommenger B, Stanek C, Cuny C Methicillinresistant Staphylococcus aureus ST398 in humans and animals, Central Europe. Emerg Infect Dis. 2007;13: 25558.

20. Zhao C, Liu Y, Zhao M, Liu Y, Yu Y, et al. Characterization of Community Acquired Staphylococcus aureus Associated with Skin and Soft Tissue Infection in Beijing: High Prevalence of PVL+ ST398. PLOS ONE. 2012;7(6): 1-6.

21. Graveland $H$, Wagenaar JA, Bergs $K$, Heesterbeek $H$ Heederik D. Persistence of Livestock Associated MRSA CC398 in Humans Is Dependent on Intensity of Animal Contact. PLoS ONE. 2011;6(2):1-7.

22. Wassenberg MWM, Bootsma MCJ, Troelstra A, Kluytmans JAJW and Bonten MJM. Transmissibility of livestockassociated methicillin-resistant Staphylococcus aureus (ST398) in Dutch hospitals. Clin Microbiol Infect 2011;17(2):316-19.

23. Smith TC, Pearson N. The emergence of Staphylococcus aureus ST398. Vector Borne Zoonotic Dis. 2011;11(4): 32739.

24. Ip M, Yung RW, Ng TK, Luk WK, Tse C, Hung P, Enright M, Lyon DJ. Contemporary methicillin-resistant Staphylococcus aureus clones in Hong Kong. J Clin Microbiol. 2005;43:506973.

25. Methicillin-resistant Staphylococcus aureus Backgrounder. American Veterinary Medical Association. 2009 June 24.

26. Gottschalk $M$ and Segura $M$. The pathogenesis of the meningitis caused by Streptococcus suis: the unresolved questions. Vet Microbiol. 2000;76(3):259-72.

27. King SJ, Heath PJ, Luque I, Tarradas C, Dowson CG, Whatmore AM. Distribution and genetic diversity of suilysin in Streptococcus suis isolated from different disease of pigs and characterization of the genetic basis of suilysin absence. Infect Immun.. 2001;69(12):7572-82.

28. Wertheim FL, Nghia HT, Taylor W, Schultsz C. Streptococcus suis: An Emerging Human Pathogen. Clin Infect Dis. 2009;48(5):617-25.

29. Papatsiros VGP, Vourvidis D, Tzitzis AA, et al. Streptococcus suis: an important zoonotic pathogen for human - prevention aspects. Veterinary World. 2011;4(5):216-21.

30. Lun ZR, Wang QP, Chen XG, Li AX, Zhu XQ. Streptococcus suis: an emerging zoonotic pathogen. Lancet Infect Dis. 2007;7(3):201-09.

31. Wisselink HJ, Smith HE, Stockhofe-Zurwieden N, Peperkamp $\mathrm{K}$, Vecht $\mathrm{U}$. Distribution of capsular types and production of muramidase-released protein (MRP) and extracellular factor (EF) of Streptococcus suis strains isolated from diseased pigs in seven European countries. Vet Microbiol. 2000;74(3):237-48.

32. Staats JJ, Feder I, Okwumabua O, Chengappa MM. Streptococcus suis: past and present. Vet Res Commun. 1997;21(6):381-07.

33. Willenburg KS, Sentochnik DE, Zadoks RN. Human Streptococcus suis meningitis in the United States. N Engl J Med. 2006;354:1325.

34. $\mathrm{Yu} \mathrm{H}$, Jing $\mathrm{H}$, Chen $\mathrm{Z}$, et al. Human Streptococcus suis outbreak, Sichuan, China. Emerg Infect Dis. 2006;12(6):91420.

35. Mai NT, Hoa NT, Nga TV, et al. Streptococcus suis meningitis in adults in Vietnam. Clin Infect Dis. 2008;46:659-67.

36. Wertheim HFL, Nguyen HN, Taylor W, et al. Streptococcus suis, an Important Cause of Adult Bacterial Meningitis in Northern Vietnam. PLoS ONE. 2009;4(6):1-5.

37. Boonyagars L, Chongtrakool $\mathrm{P}$, Watcharananan SP Meningitis and Spondylodiscitis Due to Streptococcus suis. Journal of Infectious Diseases and Antimicrobial Agents. 2010;27:129-33.

38. Mazokopakis EE, Kofteridis DP, Papadakis JA, Gikas AH, Samonis GJ. First case report of Streptococcus suis septicaemia and meningitis from Greece. Eur J Neurol. 2005;12(6):487-89.

39. van de Beek D, Spanjaard L, de Gans J. Streptococcus suis meningitis in the Netherlands. J Infect. 2008:57(2):158-61.

40. Kopic J, Paradzik MT, Pandak N, et al. Streptococcus suis infection as a cause of severe illness: 2 cases from Croatia. Scand J Infect Dis. 2002:34(9):683-84

41. Robertson, ID, Blackmore, DK. Occupational exposure to Streptococcus suis type 2. Epidemiol Infect.1989;103:157-64.

42. Smith, TC, Capuano, AW, Boese, B, Myers, KP, Gray, GC. Exposure to Streptococcus suis among US swine workers. Emerg Infect Dis. 2008;14:1925-27.

43. Gottschalk, M. Porcine Streptococcus suis strains as potential sources of infection in humans: an underdiagnosed problem in North America? J Swine Health Prod. 2004; 12:197-99.

44. Hall I, O'Toole E. Intestinal flora in newborn infants. Am J Dis Child.1935;49:390. 
45. Larson $\mathrm{HE}$, Price $\mathrm{AB}$, Honour $\mathrm{P}$, Borriello SP. Clostridium difficile and the aetiology of pseudomembranous colitis. $\mathrm{J}$ Lancet. 1978;1:1063-66.

46. Songer JG. The emergence of Clostridium difficile as a pathogen of food animals. Anim Health Res Rev. 2004;5(2):321-26.

47. Kelly CP, Pothoulakis C, LaMont JT. Clostridium difficile colitis N Engl J Med. 1994;330:257-62.

48. Kelly CP, LaMont JT. Clostridium difficile infection. Annu Rev 1998;49:375-90.

49. Rupnik M, Wilcox MH. and Gerding DN. Clostridium difficile infection: new developments in epidemiology and pathogenesis. Nature. 2009;7:526-36.

50. Yaeger, M, Funk, N, Hoffman, L. A survey of agents associated with neonatal diarrhea in lowa swine including Clostridium difficile and porcine reproductive and respiratory syndrome virus. J Vet Diagn Invest. 2002;14:281-87.

51. Neutkens D. New Clostridium Claiming Baby Pigs. National Hog Farmer Magazine, 2001:15.

52. Weese JS, Wakeford R, Reid-Smith R, Rousseau J, Friendship R. Longitudinal investigation of Clostridium difficile shedding in piglets. Anaerobe. 2010;16(5):501-04.

53. Kuijper EJ, Coignard B, Tull P. Emergence of Clostridium difficile-associated disease in North America and Europe. Clin Microbiol Infect. 2006;12:2-18.

54. Keel K, Brazier JS, Post KW, Weese S, and Songer JG. Prevalence of PCR ribotypes among Clostridium difficile isolates from pigs, calves, and other species. J. Clin Microbiol. 2007;45:1963-64.

55. Squire MM, Riley TV, eds. Clostridium difficile Infection in Humans and Piglets: A 'One Health Opportunity. Curr Top Microbiol Immunol. Springer-Verlag Berlin Heidelberg, 2012.

56. Debast SB, van Leengoed LAMG, Goorhuis $A$, et al Clostridium difficile PCR ribotype 078 toxinotype $V$ found in diarrhoeal pigs identical to isolates from affected humans. Environ Microbiol. 2009;11(2):505-11.

57. Goorhuis A, Bakker D, Corver $\mathrm{J}$ et al. Emergence of Clostridium difficile infection due to a new hypervirulent strain, polymerase chain reaction ribotype 078. Clin Infect Dis. 2008;47-1162-70.

58. Rupnik, M., Widmer A, Zimmermann O, Eckert C, Barbut, F. Clostridium difficile toxinotype $\mathrm{V}$, ribotype 078 , in animals and humans. J Clin Microbiol. 2008;46:2146.

59. Burns K, Morris-Downes M., Fawley WN, Smyth E, Wilcox MH Fitzpatrick $F$. Infection due to $C$. difficile ribotype 078: first report of cases in the Republic of Ireland. J Hosp Infect. 2010;75-287-91.

60. Squire MM and Riley TV. Clostridium difficile infection: the next big thing! Journal of the Australian society for microbiology inc. 2012;33(4):163-64.

61. Van Reeth $\mathrm{K}$, Brown $\mathrm{IH}$, Olsen CW. Influenza Virus. Zimmerman JJ, Karriker LA, Ramirez A, Schwartz KJ, Stevenson GW, eds. Diseases of swine. 10th ed. Chichester, West Sussex: John Wiley and Sons, Inc., 2012:40.

62. Myers KP, Olsen CW, Gray GC. Cases of swine influenza in humans: a review of the literature. Clin Infect Dis. 2007;44(8):1084-88.

63. Shope $R$, Lewis $P$. Swine influenza: experimental transmission and pathology. J Exp Biol.1931;54(3):349-59.

64. Schnitzler SU, Schnitzler P. An update on swine-origin influenza virus $\mathrm{A} / \mathrm{H} 1 \mathrm{~N} 1$ : a review. Virus Genes. 2009;39(3):279-92.
65. Ding N, Wu N, Xu Q, Chen K, Zhang C. Molecular evolution of novel swine-origin $\mathrm{A} / \mathrm{H} 1 \mathrm{~N} 1$ influenza viruses among and before human. Virus Genes. 2009;39(3):293-00.

66. Van Reeth K. Avian and swine influenza viruses: our current understanding of the zoonotic risk. Vet Res. 2007;38:243-60.

67. Shinde V, Bridges CB, Uyeki TM, et al. Triple-Reassortant Swine Influenza A (H1) in Humans in the United States, 20052009. N Engl J Med. 2009;360:2616-25.

68. Vincent $A L$, Swenson SL, Lager KM, et al. Characterization of an influenza $A$ virus isolated from pigs during an outbreak of respiratory disease in swine and people during a county fair in the United States. Vet Microbiol. 2009;137:51-59.

69. Brown IH. The epidemiology and evolution of influenza viruses in pigs. Vet Microbiol. 2000;74:29-46

70. Zhou NN, Senne DA, Landgraf JS et al. Genetic reassortment of avian, swine, and human influenza $A$ viruses in American pigs. J Virol. 1999;73:8851-56.

71. Karasin Al, Carman S, Olsen CW. Identification of human H1N2 and human-swine reassortant $\mathrm{H} 1 \mathrm{~N} 2$ and $\mathrm{H} 1 \mathrm{~N} 1$ influenza A viruses among pigs in Ontario, Canada (2003 to 2005). J Clin Microbiol. 2006;44:1123-26.

72. Kida $\mathrm{H}$, Shortridge KF, Webster RG. Origin of the haemagglutinin gene of $\mathrm{H} 3 \mathrm{~N} 2$ infuenza viruses from pigs. Virology. 1988;162:160-166.

73. Nerome K, Kanegae Y., Shortridge KF, SugitaS, Ishida, M. Genetic analysis of porcine H3N2 viruses originating in southern China. J Gen Virol. 1995;76:613-24.

74. Peiris JSM, Guan Y, Markwell D, Ghose P, Webster RG Shortridge KF. Cocirculation of avian H9N2 and contemporary human" H3N2 influenza A viruses in pigs in southeastern China: potential for genetic reassortment? J Virol. 2001; 75:9679-89.

75. Garten RJ, Davis CT, Russell CA, et al. Antigenic and genetic characteristics of swine-origin $2009 \mathrm{~A}(\mathrm{H} 1 \mathrm{~N} 1)$ influenza viruses circulating in humans. Science. 2009;325:197-01.

76. Smith GJD, Vijaykrishna D, Bahl J, et al. Origins and evolutionary genomics of the 2009 swine-origin H1N1 influenza A epidemic. Nature. 2009;459:1122-25.

77. Dalton HR, Bendall R, ljaz S, Banks M. Hepatitis E: an emerging infection in developed countries. Lancet Infect Dis. 2008;8(11):698-09.

78. Barredo FS, Galiana C, Garcia A, et al. Detection of hepatitis E virus shedding in feces of pigs at different stages of production using reverse transcription-polymerase chain reaction. Journal of Veterinary Diagnostic Investigation. 2006:18(5):462-65.

79. Meng X.J. Hepatitis E virus: Animal reservoirs and zoonotic risk. Vet Microbiol. 2010;140:256-65.

80. Meng $\mathrm{XJ}$. Recent advances in hepatitis $\mathrm{E}$ virus. J Viral Hepat. 2010;17(3):153-61.

81. Meng X.J, Purcell RH, Halbur PG, et al. A novel virus in swine is closely related to the human hepatitis $E$ virus. Proceeding of the National. Academy of Sciences of the United States of America. 1997;94(18):9860-65.

82. Schlauder GG, Dawson GJ, Erker JC, et al. The sequence and phylogenetic analysis of a novel hepatitis $E$ virus isolated from a patient with acute hepatitis reported in the United States. J Gen Virol. 1998;79(3):447-56.

83. Purcell, RH, Emerson, SU. Hepatitis E: an emerging awareness of an old disease. J Hepatol. 2008;48:494-03.

84. Clemente CP, Pina $S$, Buti $M$, et al. Hepatitis $E$ virus epidemiology in industrialized countries. Emerg Infect Dis 2003;9(4):448-54. 
85. Meng, XJ, Swine hepatitis E virus: cross-species infection and risk in xenotransplantation. Curr Top Microbiol Immunol. 2003;278:185-16.

86. Cooper K, Huang FF, Batista L, et al. Identification of genotype 3 hepatitis $E$ virus (HEV) in serum and faecal samples from pigs in Thailand and Mexico, where genotype 1 and 2 HEV strains are prevalent in the respective human populations. $J$ Clin Microbiol. 2005;43:1684-88.

87. Hsieh SY, Meng JJ, Wu YH et al. Identity of a Novel Swine Hepatitis E Virus in Taiwan Forming a Monophyletic Group with Taiwan Isolates of Human Hepatitis E Virus. J Clin Microbiol.1999;37(12):3828-34.

88. Meng $\mathrm{XJ}$, Wiseman $\mathrm{B}$, Elvinger $\mathrm{F}$, et al. Prevalence of antibodies to hepatitis $\mathrm{E}$ virus in veterinarians working with swine and in normal blood donors in the United States and other countries. J Clin Microbiol. 2002;40(1):117-22.

89. Withers MR, Correa MT, Morrow M, et al. Antibody levels to hepatitis $E$ virus in North Carolina swine workers, non-swine workers, swine and murids. Am J Trop Med Hyg. 2002;66(4):384-88.

90. Kasorndorkbua C, Opriessnig T, Huang FF, et al. Infectious swine hepatitis $E$ virus is present in pig manure storage facilities on United States farms, but evidence of water contamination is lacking. Appl Environ Microbiol 2005;71:7831-37.

91. Clemente CP, Pina S, Buti $M$, et al. Hepatitis $E$ virus epidemiology in industrialized countries. Emerg Infect Dis. 2003;9(4):448-54.

92. Widdowson MA, Jaspers WJ, van der Poel WH, et al. Cluster of cases of acute hepatitis associated with hepatitis $E$ virus infection acquired in the Netherlands. Clin Infect Dis. 2003;36(1):29-33.

93. Chapman BA, Burt MJ, Wilkinson ID, Schousboe MI. Community acquired viral hepatitis in New Zealand: a case of sporadic hepatitis $E$ virus infection. Aust $N Z \mathrm{~J}$ Med 1993;23(6):722-23.

94. Chua KB, Bellini WJ, Rota PA, et al. Nipah virus:a recently emergent deadly paramyxovirus. Science. 2000;288:1432-35.

95. Kirkland PD, Stephano A. Hana M. Weingartl. Paramyxoviruses. Zimmerman JJ, Karriker LA., Ramirez A, Schwartz KJ, Stevenson GW, eds. Diseases of swine. 10th ed. Chichester, West Sussex: John Wiley and Sons, Inc., 2012:41.

96. Hendra and Nipah virus diseases. Manual of Diagnostic Tests and Vaccines for Terrestrial Animals 2012. Web site http://www.oie.int/international-standard-setting/terrestrialmanual/access-online/ Accessed August 6, 2012.

97. Weingartl $\mathrm{H}$, Czub $\mathrm{S}$, Copps $\mathrm{J}$, et al. Invasion of the central nervous system in a porcine host by nipah virus. J Virol. 2005;79(12):7528-34.

98. Daniels PW. The Nipah virus outbreak in Malaysia: Overview of the outbreak investigation and the issues that remain Proceedings: $16^{\text {th }}$ International Pig Veterinary Society Congress. 2000;553-54.

99. Field $\mathrm{H}$, Young $\mathrm{P}$, Yob JM, et al. The natural history of Hendra and Nipah viruses. Microbes Infect. 2001;3(4):307-14.

100. Yob JM, Field H, Rashdi AM, Morrissy C, et al. Nipah Virus Infection in Bats (Order Chiroptera) in Peninsular Malaysia. Emerg Infect Dis. 2001;7(3):439-41.

101. Chua, K. B. Nipah virus outbreak in Malaysia. J Clin Virol. 2003;26(3):265-75.

102. Parashar UD, Sunn LM, Ong F et al. Case-Control Study of Risk Factors for Human Infection with a New Zoonotic Paramyxovirus, Nipah Virus, during a 1998-1999 Outbreak of Severe Encephalitis in Malaysia. J Infect Dis. 2000;181(5):1755-59.
103. Kirkland PD, Stephano A. Paramyxoviruses Rubulavirus, Menangle, and Nipah Virus Infections. Straw BE, Zimmerman JJ, D'Allaire S, Taylor DJ, eds. Diseases of Swine. 9th ed. lowa: Blackwell Publishing, 2006:27.

104. Muniandy N. Serological screening using ELISA for IgG and IgM. In Report of the regional seminar on Nipah virus infection. Tokyo, Office International des Epizooties Representation for Asia and the Pacific, 2001:73-76.

105. Gurley ES, Montgomery JM, Hossain MJ, et al. Person-toPerson Transmission of Nipah Virus in a Bangladeshi Community. Emerg Infect Dis. 2007:13(7):1031-37.

106. Chadha MS, Comer JA, Lowe L, et al. Nipah Virus-associated Encephalitis Outbreak, Siliguri, India. Emerg Infect Dis. 2006;12(2):235-40.

107. Hsu VP, Hossain MJ, Parashar UD, et al. Nipah virus encephalitis reemergence, Bangladesh. Emerg Infect Dis. 2004:10(12):2082-87.

108. Luby SP, Rahman M, Hossain MJ, et al. Foodborne transmission of Nipah virus, Bangladesh. Emerg Infect Dis. 2006:12(12):1888-94.

109. Bellini WJ, Harcourt BH, Bowden N, Rota PA. Review Nipah virus: an emergent paramyxovirus causing severe encephalitis in humans. J Neurovirol. 2005;11(5):481-87.

110. Endy TP, Nisalak A. Japanese encephalitis virus: ecology and epidemiology. Curr Top Microbiol Immunol. 2002;267:11-48.

111. Fujita T. Studies on the causative agent for epidemic encephalitis. Jpn J Exp Med. 1933;17:1441-01.

112. Williams DT, Mackenzie JS, Daniels PW. Flaviviruses. Zimmerman JJ, Karriker LA, Ramirez A, Schwartz KJ, Stevenson GW, eds. Diseases of swine. 10th ed. Chichester, West Sussex: John Wiley and Sons, Inc, 2012:37.

113. Van den Hurk AF, Ritchie SA, Mackenzie JS. Ecology and geographical expansion of Japanese encephalitis virus. Ann Rev Entomol. 2009;54:17-35.

114. Johnsen DO, Edelment R, Grossman RA, et al. Study of Japanese encephalitis virus in Chiangmai Valley, Thailand V. animal infections. Am J Epidemiol. 1974;100(1):57-68.

115. Erlanger TE, Weiss S, Keiser J, Utzinger J, Wiedenmayer K. Past, Present, and Future of Japanese Encephalitis. Emerg Infect Dis. 2009;15(1):1-7.

116. Oya A, Kurane I. Japanese Encephalitis for a Reference to International Travelers. J Travel Med. 2007;14(4):259-68. 